\title{
STATUS GIZI, PENYAKIT KRONIS, DAN KONSUMSI OBAT TERHADAP KUALITAS HIDUP DIMENSI KESEHATAN FISIK LANSIA
}

\author{
Novita Kurnia Sari, Adriyan Pramono*) \\ Program Studi Ilmu Gizi Fakultas Kedokteran Universitas Diponegoro \\ Jl.Dr.Sutomo No.18, Semarang, Telp (024) 8453708, Email : gizifk@undip.ac.id
}

\begin{abstract}
Background : Elderly population percentage has significantly increased in Indonesia in the lately 30 years. The increased of this quantity must be balanced with the increase of elderly quality of life. Quality of life, especially physical health dimension may be contributed by nutritional status, chronic disease occurence and drug consumption.

Objective : To analyze the correlation between nutritional status, chronic disease occurence, and drug consumption with quality of life dimension physical health in elderly.

Method : This was cross sectional study. Population was elderly in North Cilacap subdistrict. Consecutive sampling was conducted to 58 elderly with age range 65-75 y.o, who was able to communicate well and actively participate in Posyandu. Quality of life dimension physical health data was collected using WHOQoL-BREF questionnaire by interview. The nutritional status was determined by Body Mass Index (BMI). Height was predicted by arm span convertion.

Result : There was 17,2\% underweight elderly, 46,6\% was normal, and 36,2\% was overweight. Result showed that $87,9 \%$ elderly has good quality of life dimension physical health. The occurence of chronic disease $(r=-0,449$; $p=0,000)$ and drug consumption $(r=-0,299 ; p=0,023)$ correlated with quality of life dimension physical health but nutritional status is not correlated ( $r=0,090 ; p=0,501)$.

Conclusion : Chronic disease occurence and drug consumption are correlated with quality of life dimension physical health in elderly at North Cilacap Community Health Center work area.

Keywords: quality of life; physical health dimension; nutritional status; chronic disease; drug
\end{abstract}

\section{ABSTRAK}

Latar Belakang : Persentase penduduk lanjut usia di Indonesia mengalami peningkatan yang signifikan selama 30 tahun terakhir. Peningkatan kuantitas lansia tersebut seharusnya diimbangi dengan peningkatan kualitas hidup lansia. Kualitas hidup khususnya dimensi kesehatan fisik diduga dipengaruhi oleh status gizi. Kejadian penyakit kronis dan konsumsi obat-obatan juga diketahui menurunkan kualitas hidup dimensi kesehatan fisik.

Tujuan : Mengetahui hubungan status gizi, kejadian penyakit kronis dan konsumsi obat-obatan dengan kualitas hidup dimensi kesehatan fisik pada lanjut usia.

Metode : Penelitian ini menggunakan rancangan cross sectional. Populasi adalah lansia di Kecamatan Cilacap Utara. Subjek adalah 58 orang lansia berumur 65-75 tahun yang mampu berkomunikasi dengan baik dan aktif datang ke posyandu. Subjek dipilih secara consecutive sampling. Kualitas hidup dimensi kesehatan fisik diperoleh dengan wawancara menggunakan kuesioner WHOQoL-BREF. Penentuan status gizi menggunakan IMT. Tinggi badan yang digunakan adalah tinggi badan prediksi yang diperoleh dari konversi panjang rentang tangan.

Hasil : Sebanyak 17,2\% lansia mengalami gizi kurang, 46,6\% gizi normal, dan 36,2\% gizi lebih. Sebanyak 87,9\% subjek memiliki kualitas hidup dimensi kesehatan fisik baik. Kejadian penyakit kronis $(r=-0,449 ; p=0,000)$ dan konsumsi obat-obatan $(r=-0,299 ; p=0,023)$ berhubungan dengan kualitas hidup dimensi kesehatan fisik tetapi status gizi tidak $(r=0,090 ; p=0,501)$.

Simpulan : Penyakit kronis dan konsumsi obat-obatan menurunkan kualitas hidup dimensi kesehatan fisik pada lansia di wilayah kerja Puskesmas Cilacap Utara I.

Kata Kunci: kualitas hidup; dimensi kesehatan fisik; status gizi; penyakit kronis; obat-obatan

\section{PENDAHULUAN}

Persentase penduduk lanjut usia di Indonesia mengalami peningkatan yang siginifikan selama 30 tahun terakhir dari $4,48 \%$ pada tahun 1971 menjadi $8,37 \%$ pada tahun $2009 .^{1}$ World Health Organization (WHO) memproyeksikan pada tahun 2020 persentase penduduk lansia mencapai $11,34 \%$, yang berarti lebih banyak dari persentase balita $(6,9 \%)$. Persentase penduduk lansia tertinggi di Indonesia berada di provinsi DI Yogyakarta yaitu $14,04 \%$ diikuti dengan provinsi Jawa Tengah $(11,16 \%)$ dan Jawa Timur $(11,14 \%){ }^{2}$ Peningkatan jumlah populasi penduduk lanjut usia merupakan dampak dari peningkatan Usia Harapan Hidup (UHH). Angka harapan hidup penduduk Indonesia meningkat dari 66,2 tahun 
pada tahun 2006 menjadi 70,7 tahun pada tahun 2008. ${ }^{3}$ Peningkatan kuantitas lansia tersebut harus dimbangi dengan peningkatan kualitas hidup lansia. Selain dapat berumur panjang, lansia diharapkan dapat memiliki kualitas hidup yang baik, tetap sehat, produktif, dan mandiri sehingga tidak menjadi beban bagi keluarga dan pemerintah serta tetap dapat menjadi aset negara yang bermanfaat. ${ }^{1}$

Kualitas hidup (Quality of Life) merupakan persepsi individu secara keseluruhan mengenai kebahagiaan dan kepuasan dalam kehidupan dan lingkungan sekitar dimana dia hidup. Kualitas hidup diartikan juga sebagai evaluasi dari kepuasan secara keseluruhan dari kehidupan seseorang. Dilihat dari dimensi kesehatan fisik, kualitas hidup merupakan evaluasi kepuasan terhadap rasa sakit dan ketidaknyamanan, kebugaran dan tenaga, kualitas tidur, serta ketergantungan obat yang dialami oleh seorang individu. Hal ini tentunya sesuai dengan konsep sehat WHO yang mendefinisikan bahwa sehat merupakan keadaan sejahtera meliputi fisik, mental, sosial yang tidak hanya bebas dari penyakit atau cacat secara fisik tetapi mampu merasa sejahtera, bahagia dalam kehidupan sehingga mampu mengatasi tantangan hidup sehari-hari. Peningkatan usia harapan hidup diharapkan sejalan dengan kualitas hidup yang baik dan tidak menurun, dengan menerapkan program pemberdayaan lansia untuk meningkatkan kualitas hidup dan status kesehatan mereka. ${ }^{4}$

Kualitas hidup tidak hanya dipengaruhi oleh faktor-faktor psikologis dan sosial ekonomi, tetapi juga status gizi. Masalah gizi pada lansia perlu menjadi perhatian khusus karena dapat mempengaruhi status kesehatan, penurunan kualitas hidup, dan mortalitas. Gizi kurang maupun gizi lebih pada masa dewasa akhir dapat memperburuk kondisi fungsional dan kesehatan fisik. ${ }^{5,6}$ Hal ini menunjukkan pentingnya status gizi yang normal untuk lansia. Di Indonesia, lansia yang tinggal di daerah perkotaan mengalami status gizi kurang sebesar $3,4 \%$, berat badan kurang $28,3 \%$, berat badan lebih $6,7 \%$, obesitas $3,4 \%$ dan berat badan ideal $42,4 \%{ }^{7}$

Peningkatan populasi lansia tentunya juga akan diikuti dengan peningkatan risiko menderita penyakit kronis seperti diabetes mellitus, penyakit muskuloskeletal, penyakit jantung koroner, dan hipertensi. Adanya penyakit kronis pada lansia dapat menurunkan kualitas hidup khususnya dimensi kesehatan fisik. ${ }^{8}$ Penyakit kronis yang dialami tersebut tentunya juga akan diikuti dengan konsumsi obat-obatan. Konsumsi obat-obatan pada lansia diketahui mempengaruhi kualitas hidup. Penurunan fungsi fisik serta adanya gejala dan keluhan karena penyakit kronis sering menyebabkan lansia mengonsumsi lebih dari 1 jenis obat. Penggunaan lebih dari 1 jenis obat tersebut berkaitan dengan penurunan kualitas hidup dimensi kesehatan fisik. ${ }^{9}$

Masalah kualitas hidup semakin mendapat perhatian di negara-negara maju disamping masalah kesehatan yang selama ini muncul. Kualitas hidup dalam konteks populasi sering dijadikan evaluasi terhadap intervensi dan studi klinis. Penelitian ini bertujuan untuk mengetahui hubungan antara status gizi, kejadian penyakit kronis, dan konsumsi obat-obatan dengan kualitas hidup dimensi kesehatan fisik pada lanjut usia.

\section{METODE}

Penelitian ini termasuk dalam ruang lingkup keilmuan gizi masyarakat yang dilakukan di wilayah kerja Puskesmas Cilacap Utara I pada bulan Agustus-September 2013. Jenis penelitian ini adalah penelitian analitik observasional dengan rancangan cross sectional. Populasi terjangkau adalah lansia yang secara aktif menghadiri posyandu di wilayah kerja Puskesmas Cilacap Utara I Kabupaten Cilacap. Subjek penelitian diambil dengan cara consecutive sampling sesuai kriteria inklusi sampai jumlah subjek yang diperlukan terpenuhi yaitu sebanyak 58 subjek.

Variabel bebas dalam penelitian ini adalah status gizi, kejadian penyakit kronis, dan konsumsi obat-obatan. Status gizi ditentukan melalui perhitungan Indeks Massa Tubuh (IMT) dengan pengukuran langsung berat badan dan tinggi badan yang diperoleh dari konversi panjang rentang tangan (PRT). Variabel kejadian penyakit kronis, konsumsi obat-obatan, serta karakteristik subjek meliputi umur, jenis kelamin, pendidikan, status tinggal, dan status bekerja diperoleh melalui wawancara dengan kuesioner.

Variabel terikat dalam penelitian ini adalah kualitas hidup dimensi kesehatan fisik yang diperoleh melalui wawancara dengan kuesioner WHOQoL-BREF. Terdapat 7 buah pertanyaan dalam kuesioner WHOQoL yang berisi pertanyaan tentang rasa sakit dan ketidaknyamanan, kebugaran dan tenaga, kualitas tidur, serta ketergantungan obat. Setiap pertanyaan memiliki 5 pilihan jawaban dan pilihan jawaban tersebut memiliki skor 1-5. Skor yang didapat dari setiap pertanyaan kemudian dijumlah dan dijadikan dasar pengklasifikasian kategori kualitas hidup. Skor 7 - 10 termasuk kategori kualitas hidup sangat buruk, 11 - 17 
termasuk kategori kualitas hidup buruk, $18-24$ termasuk kategori kualitas hidup kurang, 25 - 31 termasuk kategori kualitas hidup baik, dan $32-35$ termasuk kategori kualitas hidup sangat baik.

Analisis data meliputi analisis univariat dan analisis bivariat. Uji korelasi Spearman digunakan karena data berdistribusi tidak normal. Uji korelasi Spearman digunakan untuk menganalisis hubungan antara status gizi, kejadian penyakit kronis, dan konsumsi obat-obatan dengan kualitas hidup dimensi kesehatan fisik.

\section{HASIL \\ Karakteristik Subjek}

Penelitian ini dilakukan pada lansia pria maupun wanita pada kisaran umur antara 65-75 tahun. Data distribusi frekuensi dapat dilihat pada tabel di bawah ini.

Tabel 1. Distribusi frekuensi karakteristik subjek

\begin{tabular}{lll}
\hline Karakteristik Subyek & Frekuensi (n) & Persentase (\%) \\
\hline Umur & & \\
65 - 70 tahun & 45 & 77,6 \\
71 - 75 tahun & 13 & 22,4 \\
\hline Jenis kelamin & & \\
Pria & 24 & 41,4 \\
Wanita & 34 & 58,6 \\
\hline Pendidikan & \\
Pendidikan dasar & 40 & 68,9 \\
Pendidikan menengah & 15 & 25,9 \\
Pendidikan tinggi & 3 & 5,2 \\
\hline Status tinggal & & \\
Tinggal dengan pasangan & 22 & 37,9 \\
Tinggal dengan keluarga besar & 36 & 62,1 \\
\hline Status bekerja & & \\
Tidak bekerja & 23 & 39,7 \\
Bekerja & 35 & 60,3 \\
\hline
\end{tabular}

Tabel 1 menunjukkan bahwa umur subjek terbanyak berada pada rentang umur 65-70 tahun. Subjek wanita memiliki jumlah lebih besar dibandingkan subyek pria.

Tingkat pendidikan subjek sebagian besar berada pada tingkat pendidikan dasar. Tabel di atas juga menunjukkan bahwa sebagian besar subjek tinggal bersama dengan keluarga besar dan masih bekerja.

Status bekerja yang dimaksud dalam penelitian ini adalah subjek setiap harinya melakukan aktivitas yang berkaitan dengan pekerjaan baik dari sektor formal maupun informal. Sedangkan subjek yang setiap harinya hanya melakukan aktivitas seperti pekerjaan rumah tangga dan olahraga dikategorikan tidak bekerja.
Pekerjaan subjek yang ditemukan dari lapangan semuanya dari sektor informal seperti petani, nelayan, bekerja di ladang, mengajar di kursus, dan pekerjaan serabutan.

Hubungan Status Gizi, Kejadian Penyakit Kronis, dan Konsumsi Obat-Obatan dengan Kualitas Hidup Dimensi Kesehatan Fisik

Kualitas hidup dimensi kesehatan fisik subjek diperoleh melalui wawancara dengan kuesioner. Kuesioner berisi 7 buah pertanyaan mengenai kepuasan dan kebahagiaan subjek tentang rasa sakit dan ketidaknyamanan, kebugaran dan tenaga, kualitas tidur, serta ketergantungan obat. Penentuan kategori kualitas hidup dimensi kesehatan fisik didasarkan pada total skor yang didapatkan dari setiap jawaban.

Tabel 2. Distribusi Indeks Massa Tubuh dan Skor Kualitas Hidup Dimensi Kesehatan Fisik

\begin{tabular}{lccccc}
\hline \multicolumn{1}{c}{ Variabel } & Rerata \pm SD & Min & Mak & r & p \\
\hline Indeks massa tubuh $\left(\mathrm{kg} / \mathrm{m}^{2}\right)$ & $23,25 \pm 4,74$ & 12,82 & 33,42 & 0,090 & $0,501^{*}$ \\
\hline Skor kualitas hidup dimensi kesehatan fisik & $26,72 \pm 2,59$ & 15 & 30 & & \\
\hline$*$ Uji korelasi Spearman & & & & &
\end{tabular}

Rerata skor kualitas hidup subjek sebesar $26,72 \pm 2,59$ dan berada pada kategori kualitas hidup baik. Analisis deskriptif menunjukkan bahwa sebagian besar subjek memiliki kualitas hidup baik (tabel 3). 
Status gizi subjek ditentukan melalui perhitungan IMT dengan indikator berat badan dan tinggi badan. Rerata IMT subjek adalah sebesar $23,25 \pm 4,74$ dan berada pada kategori status gizi normal. Walaupun rerata IMT subjek berada pada kategori gizi normal, tetapi nilai minimal sebesar $12,82 \mathrm{~kg} / \mathrm{m}^{2}$ dan nilai maksimal sebesar 33,42 $\mathrm{kg} / \mathrm{m}^{2}$ perlu menjadi perhatian karena berada cukup jauh dari rentang normal.

Variabel kejadian penyakit kronis dalam penelitian ini adalah keberadaan satu atau beberapa jenis penyakit yang diderita subjek dalam jangka waktu lama dan menahun. Penentuan keberadaan penyakit ini didasarkan pada hasil pemeriksaan dari puskesmas, posyandu, rumah sakit serta pengakuan subjek mengenai gejala dan keluhan fisik yang dialami sampai saat penelitian berlangsung. Penyakit kronis yang ditemukan di lapangan diantaranya adalah hipertensi, diabetes mellitus, asam urat, penyakit jantung, penyakit paru kronik, dan gastritis kronis.

Variabel konsumsi obat-obatan yang dimaksud dalam penelitian ini adalah konsumsi satu atau beberapa jenis obat yang berasal dari resep dokter dan dikonsumsi secara rutin. Data konsumsi obat-obatan diperoleh dari pengamatan langsung obat yang dikonsumsi dan wawancara secara door to door.

Tabel 3. Hubungan Status Gizi, Kejadian Penyakit Kronis, dan Konsumsi Obat-Obatan dengan Kualitas Hidup Dimensi Kesehatan Fisik

\begin{tabular}{|c|c|c|c|c|c|c|}
\hline \multirow[t]{2}{*}{ Variabel } & \multicolumn{2}{|c|}{$\begin{array}{c}\text { Kualitas hidup } \\
\text { n }(\%)\end{array}$} & \multicolumn{2}{|c|}{ Total } & \multirow[t]{2}{*}{$\mathbf{r}$} & \multirow{2}{*}{$\mathbf{p}$} \\
\hline & Kurang & Baik & $\mathbf{n}$ & $\%$ & & \\
\hline $\begin{array}{l}\text { Status Gizi } \\
\text { Underweight }(<18,5 \\
\left.\mathrm{kg} / \mathrm{m}^{2}\right) \\
\text { Normal }\left(18,5-25 \mathrm{~kg} / \mathrm{m}^{2}\right) \\
\text { Overweight }\left(>25 \mathrm{~kg} / \mathrm{m}^{2}\right)\end{array}$ & $\begin{array}{l}2(3,4) \\
3(5,2) \\
2(3,4)\end{array}$ & $\begin{array}{l}8(13,8) \\
24(41,4) \\
19(32,7)\end{array}$ & $\begin{array}{l}10 \\
27 \\
21\end{array}$ & $\begin{array}{l}17,3 \\
46,6 \\
36,1\end{array}$ & 0,090 & $0,501 *$ \\
\hline $\begin{array}{l}\text { Kejadian penyakit kronis } \\
\text { Tidak menderita penyakit } \\
\text { Menderita penyakit } \\
\end{array}$ & $7(12)$ & $\begin{array}{l}32(55,2) \\
19(32,8) \\
\end{array}$ & $\begin{array}{l}32 \\
26 \\
\end{array}$ & $\begin{array}{l}55,2 \\
44,8 \\
\end{array}$ & $-0,449$ & $0,000 *$ \\
\hline $\begin{array}{l}\text { Konsumsi obat-obatan } \\
\text { Tidak mengonsumsi obat } \\
\text { Mengonsumsi obat }\end{array}$ & $\begin{array}{l}2(3,4) \\
5(8,6)\end{array}$ & $\begin{array}{l}36(62,1) \\
15(25,9)\end{array}$ & $\begin{array}{l}38 \\
20 \\
\end{array}$ & $\begin{array}{l}65,5 \\
34,5 \\
\end{array}$ & $-0,299$ & $0,023 *$ \\
\hline Total & $7(12,1)$ & $51(87,9)$ & 58 & 100 & & \\
\hline
\end{tabular}

*Uji Korelasi Spearman

Tabel 3 menunjukkan bahwa sebagian besar subjek memiliki kualitas hidup baik. Hal ini sesuai dengan pendapat sebagian besar subjek yang merasa puas dengan hidupnya walaupun terkadang kemampuan tubuh menurun saat bekerja terlalu lama. Subjek berpendapat hal tersebut dikarenakan penuaan.

Tabel 3 juga menunjukkan bahwa sebagian besar subjek memiliki status gizi normal yaitu sebanyak 27 orang $(46,6 \%)$. Dari 7 orang subjek yang memiliki kualitas hidup kurang, 2 orang diantaranya memiliki status gizi underweight, 3 orang memiliki status gizi normal, dan 2 orang sisanya memiliki status gizi overweight. Analisis bivariat menunjukkan bahwa $\mathrm{p}>0,05$ yang berarti bahwa status gizi dan kualitas hidup dimensi kesehatan fisik tidak berhubungan secara statistik.

Gambaran kejadian penyakit kronis subjek dan kualitas hidup dimensi kesehatan fisik dapat dilihat pada tabel 3. Tabel 3 menunjukkan bahwa sebagian besar subjek tidak menderita penyakit kronis $(55,2 \%)$. Semua subjek yang tidak menderita penyakit kronis memiliki kualitas hidup baik. Subjek yang memiliki kualitas hidup kurang sebanyak 7 orang (12\%) dan semuanya menderita penyakit kronis. Analisis dengan uji korelasi Spearman menunjukkan bahwa terdapat hubungan yang bermakna antara kejadian penyakit kronis dengan kualitas hidup dimensi kesehatan fisik $(\mathrm{r}=$ $0,449 ; p=0,000)$. Nilai korelasi Spearman sebesar 0,449 berarti bahwa arah korelasi negatif dengan kekuatan korelasi sedang. Hal tersebut berarti bahwa adanya penyakit kronis menurunkan kualitas hidup dimensi kesehatan fisik.

Tabel 3 juga menunjukkan gambaran konsumsi obat-obatan subjek dan kualitas hidup dimensi kesehatan fisik. Sebagian besar subjek tidak mengonsumsi obat-obatan $(65,5 \%)$. Dari 38 
orang yang tidak mengonsumsi obat-obatan $62,1 \%$ diantaranya memiliki kualitas hidup baik. Terdapat 7 orang subjek yang memiliki kualitas hidup kurang, 2 orang diantaranya tidak mengonsumsi obat-obatan sedangkan 5 orang lainnya mengonsumsi obat-obatan. Analisis bivariat menunjukkan bahwa terdapat hubungan yang bermakna antara konsumsi obat-obatan dengan kualitas hidup dimensi kesehatan fisik ( $\mathrm{r}=-0,299$; $\mathrm{p}=0,023)$. Nilai korelasi Spearman sebesar $-0,299$ berarti bahwa arah korelasi negatif dengan kekuatan korelasi yang lemah. Hal tersebut juga berarti bahwa konsumsi obat-obatan menurunkan kualitas hidup dimensi kesehatan fisik.

\section{PEMBAHASAN}

Kualitas hidup jika dilihat dari dimensi kesehatan fisik merupakan evaluasi dari kepuasan dan kebahagiaan terhadap aspek-aspek kesehatan fisik seperti rasa sakit dan ketidaknyamanan akibat penyakit, kebugaran dan tenaga, kualitas tidur, serta ketergantungan obat. Hal tersebut berarti semakin puas seseorang terhadap aspek kesehatan fisik tersebut, semakin baik pula kualitas hidupnya. Nilai kepuasan tersebut bersifat subjektif dan berbeda-beda bagi setiap orang, tentunya dipengaruhi juga oleh faktor lain di luar kesehatan.

Hasil penelitian menunjukkan bahwa sebagian besar subjek memiliki status gizi normal (Tabel 3). Namun, nilai minimal IMT sebesar $12,82 \mathrm{~kg} / \mathrm{m} 2$ perlu menjadi perhatian khusus karena jauh di bawah rentang normal. Studi yang dilakukan oleh Cook et al menunjukkan bahwa IMT $<22 \mathrm{~kg} / \mathrm{m}^{2}$ pada lansia dapat meningkatkan risiko mortalitas. ${ }^{10}$ Nilai maksimal IMT sebesar $33,42 \mathrm{~kg} / \mathrm{m}^{2}$ juga jauh di atas rentang normal. Hasil penelitian kohort pada subjek pria dan wanita berumur 50-71 tahun menyatakan bahwa risiko mortalitas meningkat pada subjek yang kelebihan berat badan termasuk overweight. ${ }^{11}$

Penelitian ini menunjukkan bahwa tidak ada hubungan yang bermakna secara statistik antara kualitas hidup dimensi kesehatan fisik dengan status gizi $(p>0,05)$. Hal ini sejalan dengan penelitian Hickson \& Frost yang menyatakan bahwa status gizi tidak secara langsung mempengaruhi kualitas hidup. Status gizi mungkin mempengaruhi kualitas hidup melalui penurunan fungsi fisik yang terjadi pada lansia. Selain itu studi tersebut juga menyatakan faktor yang mempengaruhi asupan makanan seperti kemampuan menelan dan nafsu makan lebih mempengaruhi kualitas hidup dibandingkan status gizi. ${ }^{12}$ Namun, hal ini tidak sesuai dengan penelitian yang dilakukan oleh Pramoni yang menyatakan bahwa status gizi dan asupan zat gizi memiliki hubungan yang signifikan dengan kualitas hidup secara keseluruhan. ${ }^{13}$

Penelitian yang dilakukan oleh Wa Ode juga menyebutkan bahwa terdapat hubungan antara status gizi dengan kualitas hidup pada dimensi kesehatan fisik. ${ }^{14}$ Hal tersebut bisa terjadi karena penyebab baik atau buruknya kualitas hidup setiap orang berbeda-beda dan status gizi bukan merupakan satu-satunya hal yang dijadikan indikator untuk mengukur kualitas hidup khususnya dimensi kesehatan fisik. Terdapat banyak faktor lain yang mempengaruhi kualitas hidup diantaranya adanya keluhan dan penyakit kronis, tingkat pendidikan, serta lingkungan fisik dan sosial dimana individu itu tinggal. ${ }^{15}$

Variabel lain yang diteliti dalam penelitian ini adalah kejadian penyakit kronis. Berdasarkan hasil penelitian sebagian besar subjek tidak menderita penyakit kronis $(55,2 \%)$ dan semuanya memiliki kualitas hidup baik. Subjek juga jarang mengalami keluhan-keluhan fisik yang menghambat aktivitas. Penyakit-penyakit kronis yang ditemukan pada subjek diantaranya adalah hipertensi, diabetes mellitus, asam urat, penyakit jantung, penyakit paru kronik, dan gastritis kronis. Hasil analisis bivariat menunjukkan bahwa terdapat hubungan yang bermakna secara statistik $(p<0,05)$ antara kejadian penyakit kronis dengan kualitas hidup dimensi kesehatan fisik. Hubungan tersebut memiliki arah negatif dengan kekuatan korelasi sedang $(r=-0,449)$. Hal ini berarti bahwa adanya penyakit kronis dapat menurunkan kualitas hidup dimensi kesehatan fisik.

Hal ini sesuai dengan penelitian sebelumya yang menyatakan bahwa kualitas hidup domain fisik dan lingkungan pada lansia yang mengalami penyakit kronis lebih rendah secara bermakna dibandingkan lansia yang tidak mengalami penyakit kronis. ${ }^{16}$ Namun, hasil penelitian ini bertentangan dengan penelitian Yuniarti yang menunjukkan tidak adanya hubungan antara penyakit kronis dengan kualitas hidup lansia. ${ }^{17} \mathrm{Hal}$ ini mungkin bisa terjadi karena kualitas hidup bukan hanya dipengaruhi oleh ada atau tidaknya penyakit tetapi juga dipengaruhi oleh keluhankeluhan fisik yang berkaitan dengan derajat/stadium penyakit. ${ }^{18}$ Sedangkan untuk menentukan jenis penyakit mana yang paling berhubungan dengan kualitas hidup khususnya dimensi kesehatan fisik sangat sulit dilakukan. Hal itu dikarenakan penilaian subyektif masing-masing individu sejauh mana penyakit yang diderita 
mempengaruhi kemampuannya dalam beraktivitas sehari-hari. ${ }^{19}$

Penyakit kronis mempengaruhi kualitas hidup dimensi kesehatan fisik karena dapat membatasi individu untuk melakukan aktivitas yang dianggapnya penting. Adanya penyakit kronis juga mengganggu kontrol perasaan seseorang terhadap dirinya. Seseorang dengan penyakit kronis cenderung membandingkan keadaan dirinya dengan orang lain yang lebih sehat. ${ }^{8}$

Variabel lain dalam penelitian ini adalah konsumsi obat-obatan. Berdasarkan hasil penelitian ini sebagian besar subjek tidak mengonsumsi obat-obatan $(65,5 \%)$. Hal ini berkaitan dengan tidak adanya penyakit kronis yang diderita subjek. Analisis bivariat menunjukkan bahwa terdapat hubungan yang bermakna antara konsumsi obat-obatan dengan kualitas hidup dimensi kesehatan fisik $(p<0,05)$. Arah hubungan tersebut adalah negatif dengan kekuatan korelasi lemah $(r=-0,299)$. Hal ini berarti bahwa konsumsi obat-obatan menurunkan kualitas hidup dimensi kesehatan fisik.

Hasil penelitian ini sejalan dengan studi yang dilakukan oleh Henderson et al yang menunjukkan bahwa polifarmasi memiliki hubungan dengan kualitas hidup komponen kesehatan fisik bahkan setelah dilakukan kontrol terhadap umur, jenis kelamin, dan penyakit kronis. ${ }^{9}$ Hal ini juga didukung oleh penelitian Kovac et al yang menyebutkan bahwa penggunaan obat ganda berhubungan dengan kualitas hidup komponen kesehatan fisik. Penelitian ini menyebutkan bahwa penggunaan obat ganda berhubungan dengan rendahnya kualitas hidup komponen kesehatan fisik setelah dilakukan kontrol terhadap faktor klinis dan demografis. Hal itu dapat disebabkan karena seseorang mungkin mengonsumsi lebih dari satu jenis obat untuk mengatasi sakit yang diderita. Namun, hal itu malah akan menambah risiko komplikasi dan tidak meredakan gejala dan keluhan yang dialami. ${ }^{20}$

\section{SIMPULAN}

Kejadian penyakit kronis dan konsumsi obat-obatan berhubungan dengan menurunnya kualitas hidup dimensi kesehatan fisik pada lanjut usia di wilayah kerja Puskesmas Cilacap Utara I. Sementara itu status gizi tidak memiliki hubungan yang bermakna dengan kualitas hidup dimensi kesehatan fisik. Status gizi mungkin secara tidak langsung mempengaruhi kualitas hidup melalui penurunan fungsi fisik.

\section{DAFTAR PUSTAKA}

1. Komisi Nasional Lanjut Usia. Profil Penduduk Lanjut Usia Tahun 2009. Jakarta: Komisi Nasional Lanjut Usia; 2010.

2. Kementerian Negara Perlindungan Perempuan an Perlindungan Anak [Internet]. Jakarta: Kementerian Negara Perlindungan Perempuan an Perlindungan Anak; 2013 [cited 26 Februari 2013]. Available from: http://www.menegpp.go.id/

3. Kementerian Negara Koordinator Bidang Ekonomi, Kesejahteraan Rakyat [Internet]. Jakarta: Kementerian Negara Koordinator Bidang Ekonomi, Kesejahteraan Rakyat; 2013 [cited 26 Februari 2013]. Available from: http://www.datakesra.menkokesra.go.id /

4. Mohan LK, Stump SE. Krause's: Food, Nutrition \& Diet Therapy. 13th ed. Pennsylvania: Elsevier; 2004.

5. McNaughton SA, Crawford D, Ball K, Salmon J, et al. Understanding Determinants Of Nutrition, Physical Activity And Quality Of Life Among Older Adults: The Wellbeing, Eating And Exercise For A Long Life (WELL) Study. Australia Health and Quality of Life Outcomes. 2012;109(10): 2-7.

6. Drewnowski A, Evans WJ. Nutrition, Physical Activity, and Quality of Life in Older Adults: Summary. J Gerontol. 2001; 56A (Special Issue II): 89-94.

7. Darmojo B, Martono H. Buku Ajar Geriatri (Ilmu Kesehatan Tingkat Lanjut). $3^{\text {rd }}$ ed . Jakarta: Balai Penerbit FKUI; 2006.

8. Megari K. Quality Of Life In Chronic Disease Patients. Health Psychol. 2013; 1(e27): 141-148.

9. Henderson AJ, Buchwald D, Manson SM. Relationship of Medication Use to Health-Related Quality of Life Among a Group of Older American. J Appl Gerontol. 2006; 20(10): 1-15.

10. Cook Z, Kirk S, Lawrenson S, Sandford S. Use of BMI In The Assessment Of Undernutrition In Older Subjects: Reflecting On Practice. Proc Nutr Soc. 2005; 64: 313-317.

11. Adams KF, Schatzkin A, Harris T, et al. Overweight, Obesity, and Mortality in a Large Prospective Cohort of Persons 50 to 71 Years Old. N Engl J Med. 2006; 355:763-78.

12. Hickson M, Frost. G. An Investigation Into The Relationships Between Quality Of Life, Nutritional Status And Physical Function. Clin Nutr. 2004; 23: 213-221.

13. Ni Gusti AKDP. Hubungan Asupan Zat Gizi Dan Status Gizi Dengan Kualitas Hidup Peserta Posyandu Lanjut Usia di Kabupaten Sleman. (Skripsi). Yogyakarta: UGM; 2010.

14. Wa Ode S. Status Gizi Dan Kualitas Hidup Lansia Di Kabupaten Baru Kecamatan Sopengriaja Dan Mallausetasi. (Skripsi). Makassar: UMI; 2012.

15. Maryam T, Mohammad A, Ali M. Determinants Of Health-Related Quality Of Life In Elderly In 
Tehran, Iran. BMC Public Health. 2008 Sep; 323(8): 32-37.

16. Yenny, Elly H. Prevalensi Penyakit Kronis Dan Kualitas Hidup Pada Lanjut Usia di Jakarta Selatan. Universa Medicina. 2006; 25(4): 164-171.

17. Alfrina Yuniarti. Status Gizi Terkait Dengan Kualitas Hidup Lansia Di Rappokalling Makassar. (Skripsi). Makassar: UNHAS; 2013.

18. Amarantos E et al. Nutrition And Quality Of Life In Older Adults. J Gerontol. 2001; 56A(2): 54-64.

19. Hamid. (2001). Penyakit-penyakit kronis yang mempengaruhi kehidupan lansia, diakses pada tanggal $20 \quad$ Oktober 2013, <http://eprints.usu.ac.id/17322>.

20. Kovac SH, Saag KG, Curtis JR, Allison J. Association of Health-Related Quality of Life With Dual Use of Prescription and Over-theCounter Nonsteroidal Antiinflammatory Drugs. Arthrit Care Res. Feb 2008; 59 (2): 227-233. 